\title{
Passwords
}

Volume 12 | Issue 2

Article 6

6-4-2012

\section{a Catch not Caught}

Nissa Gustafson

nsg02011@mymail.pomona.edu

Follow this and additional works at: http://scholarship.claremont.edu/passwords

Part of the Creative Writing Commons

\section{Recommended Citation}

Gustafson, Nissa (2012) "a Catch not Caught," Passwords: Vol. 12: Iss. 2, Article 6. DOI: 10.5642/passwrd.20121202.6

Available at: http://scholarship.claremont.edu/passwords/vol12/iss2/6

This Poetry is brought to you for free and open access by the Journals at Claremont at Scholarship @ Claremont. It has been accepted for inclusion in

Passwords by an authorized administrator of Scholarship@ Claremont. For more information, please contact scholarship@cuc.claremont.edu. 


\section{a Catch not Caught \\ Nissa Gustafson}

More bass please,

And the Vibrations are ruining my teeth.

Wil'st thou speak me tender yonder and snatch a drip of sleep?

The crazy maiden who stays here stole all of

My Mirrors!

Slowdance blue pants and foxtrot to the moon.

I thought you just yet might join me.

Or did you call and say sorry

you just couldn't make the date?

Spin spun alone. Slide sap trombone.

Wil'st thou call later?

And I can listen to her tell you that you're too nice to me.

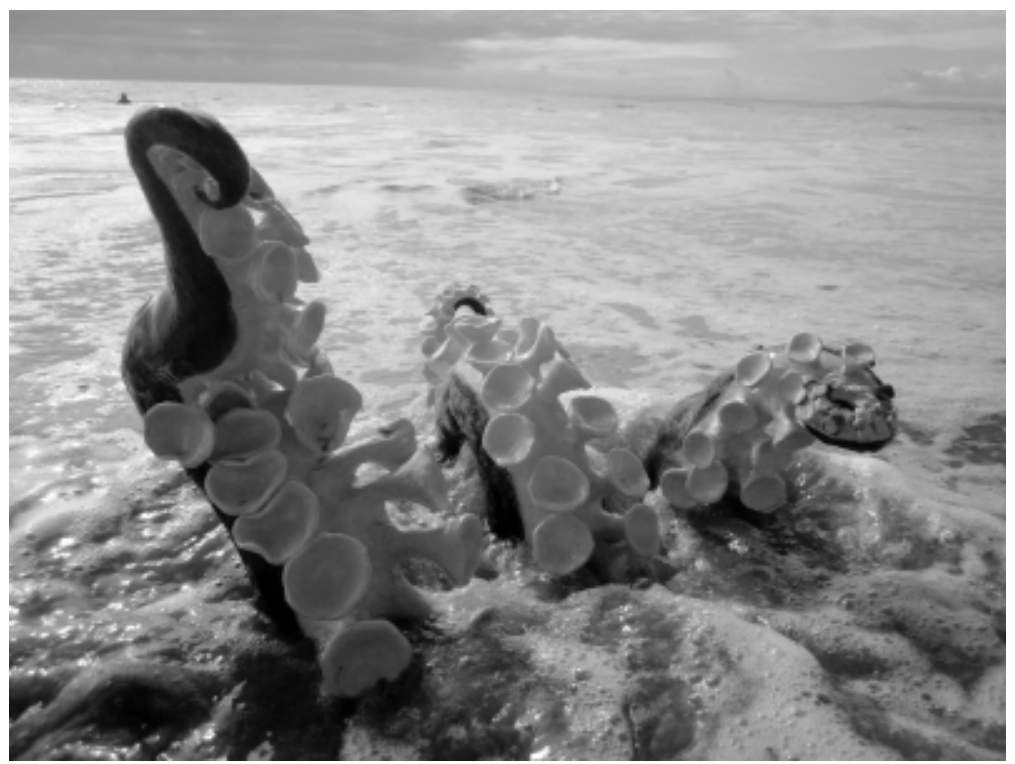

Henry $V$, Julia Rigby 